\title{
INTERNATIONAL BUSINESS KNOWLEDGE OF ENTREPRENEURS IN NARATHIWAT, THAILAND
}

\author{
MOHD RAFI YAACOB* \\ MOHD NAZRI ZAKARIA** \\ MOHAMMAD ISMAIL*** \\ ZURAIMI ABDUL AZIZ**** \\ MUHAMMAD BUGREE LEBAHANGUS ${ }^{* * * * *}$ \\ FAKHRUL ANWAR ZAINOL ${ }^{* * * * *}$
}

\begin{abstract}
Abstrak
Narathiwat merupakan sebahagian daripada 77 wilayah di Thailand yang terletak di utara negeri Kelantan, Malaysia. Majoriti penduduknya beragama Islam dan mempunyai sosio-budaya yang sama. Pelbagai produk dari Thailand dieksport ke Malaysia masuk melalui Kelantan dan sebagai salah satu prasyarat perniagaan antarabangsa, usahawan Narathiwat perlu pengetahuan dalam hal ini. Kajian ini mengukur pengetahuan perniagaan antarabangsa usahawan Narathiwat dan ini pengukuran tahap pengetahuan usahawan penting bukan sahaja mencerminkan kekuatan perniagaan merentas sempadan sekarang tetapi boleh menjadi petanda aras perancangan pelaksanaan Komuniti Ekonomi ASEAN (AEC). Dalam kajian ini, 30 usahawan mikro dan usahawan kecil daripada pelbagai perniagaan diselidiki pada April, 2014. Dengan menggunakan skala Likert, 1 pada tahap tidak tahu hingga 5 tahap sangat tahu, hasil kajian menunjukkan usahawan mempunyai pengetahuan rendah dalam semua aspek: peraturan pengurusan kewangan, dasar awam dan peluang perniagaan, AEC, rangkaian perniagaan, imej perusahaan serta logistik dan pengedaran. Penemuan ini tidak bagus dalam konteks perniagaan antarabangsa dan pada masa yang sama menimbulkan banyak persoalan. Untuk menangani hal ini, pemerintah Narathiwat dan kerajaan Thailand perlu meningkatkan pengetahuan usahawan melalui pembentukkan polisi awam untuk menyokong dan mengembangkan pengetahuan di kalangan usahawan. Dengan usaha sedemikian, usahawan di Narathiwat akan lebih bersedia untuk menyertai AEC.
\end{abstract}

Kata Kunci: Usahawan, Pengetahuan, Perniagaan Antarabangsa, Narathiwat

$\begin{array}{ll}* * & \text { Assoc. Professor, Faculty of Entrepreneurship and Business, Universiti Malaysia Kelantan, Malaysia } \\ * * & \text { Senior lecturer, Faculty of Entrepreneurship and Business, Universiti Malaysia Kelantan, Malaysia } \\ * * * & \text { Assoc. Professor, Faculty of Entrepreneurship and Business, Universiti Malaysia Kelantan, Malaysia } \\ * * * * & \text { Senior lecturer, Faculty of Entrepreneurship and Business, Universiti Malaysia Kelantan, Malaysia } \\ * * * * * & \text { District Community Development Officer, Sukhirin District, Narathiwat, Thailand } \\ \text { Assoc. Prof. Faculty of Business Management and Accountancy, Universiti Sultan Zainal Abidin, Malaysia } & \end{array}$




\begin{abstract}
Narathiwat is one of the 77 provinces in Thailand north of Kelantan, Malaysia. A majority of the population are Muslims and retain a similar socio-cultural practices as in Kelantan. At present, a variety of products from Thailand are exported to Malaysia through Kelantan. One of the prerequisites for international business is knowledge about international business. This study investigates the level of knowledge among entrepreneurs in Narathiwat on international business. Measuring such knowledge does not only reflect the intensity of business across borders at present but also provide an early indicator of such activity upon the implementation of the Asean Economic Community (AEC). In this study, 30 micro and small-size entrepreneurs of various businesses from Narathiwat were surveyed in April, 2014. Using Likert Scale ranging from 1 (no knowledge) to 5 (highly knowledgeable), the findings showed that the entrepreneurs had low knowledge in regulation, financial management, public policy and business opportunity, AEC, enterprise image, international networking and logistics, and distributive trade. These findings are alarming and raise more questions. Therefore, Narathiwat and the Thai government should improve their entrepreneurs' international knowledge by formulating a public policy to support and foster new knowledge on international business. By so doing, entrepreneurs in Narathiwat will be better prepared as the country embraces AEC.
\end{abstract}

Keywords: Entrepreneurs, Knowledge, International Business, Narathiwat

\footnotetext{
* Assoc. Professor, Faculty of Entrepreneurship and Business, Universiti Malaysia Kelantan, Malaysia

** Senior lecturer, Faculty of Entrepreneurship and Business, Universiti Malaysia Kelantan, Malaysia

*** Assoc. Professor, Faculty of Entrepreneurship and Business, Universiti Malaysia Kelantan, Malaysia

**** Senior lecturer, Faculty of Entrepreneurship and Business, Universiti Malaysia Kelantan, Malaysia

***** District Community Development Officer, Sukhirin District, Narathiwat, Thailand

****** Assoc. Prof. Faculty of Business Management and Accountancy, Universiti Sultan Zainal Abidin, Malaysia 


\subsection{Introduction}

Entrepreneurship has been around for thousands of years. However, in modern times, the word 'entrepreneurship' that connotes such a process was first used in the 1700s in Europe. Since then, much have been talked and written about it and the meaning of an entrepreneur has evolved. An entrepreneur is one who is willing to bear the risk of a new venture if there is a chance for profits. On the other hand, some define an entrepreneur as a person who organizes, operates, and assumes the risk for a business venture. Some associate an entrepreneurs' role as innovators who market their innovation or develop new goods or processes to fulfil the demands of the market. Entrepreneurship is necessary as it stimulates economic growth and employment opportunities in all societ?ies. In both the developed and developing world, successful small busi $\urcorner n e s s e s$ are the primary engines of job creation, income growth, and poverty alleviation. Therefore, the govern 7 ment's support for entrepreneurship through various means is crucial for economic development. Entrepreneurial activity leads to economic growth and creates a vibrant and competitive business environment and in turn foster stability as price of finished goods is not as volatile as commodities (Jeanne, 2007).

A person becomes an entrepreneur due to multifarious reasons: a person has been laid off; a person is frustrated with his or her curnrent job and does not see any better career prospects or realizes that his or her job is in jeopardy: a firm may have cutbacks that could end a job or stagnate career advancement and salary increment; a person is passed over for promotion and sees no oppor?tunity in the existing company; a person who dismisses the idea of working for someone else; a person is disillusioned by the bureaucracy or politics involved in getting ahead in an established business or profession and a person who is tired of trying to promote a product or service. Inversely, a person is attracted to entrepre $\urcorner$ neurship by the advantages of starting a business including: as an entrepreneur, he or she makes the decisions; he or she can choose whom to do business with and what work he or she does; he or she decides what hours to work, as well as who to pay and whether to take vacations or not.

Overall, entrepreneurship offers a greater possibility of achieving significant financial rewards than working for someone else. Indeed it provides the ability to be involved in the total operation of the business, from concept to design and creation, from sales to business operations and customer responses. It offers the prestige of being the person in charge. It gives an individual the opportunity to build equity, which can be kept, sold, or passed on to the next generation. Entrepreneurship creates an opportunity for a person to make a contribution. Some persons evaluate the possibilities for jobs and careers where they live and make a conscious decision to pursue entrepreneurship. From above reasons, no one reason is more valid than another; none guarantees success. However, a strong desire to start a business, combined with a good idea, careful planning, and hard work, can lead to a very engaging and profitable endeavor.

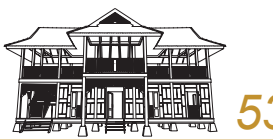


Nowadays, due to globalization, an entrepreneur not only runs a business in his or her home country. Although the word 'globalization' is rather new, cross border trade has existed for thousands of years. However, due to the advancement in information and technology, as well as transportation and custom policies that facilitate open policies of outflow and inflow of goods, the magnitude of global trade has expanded tremendously (Robert and Jack,1992). Besides Multinational Corporations (MNCs) that have dominated international business, in recent times even small and medium sized entrepreneurs have extended their businesses beyond borders (Miroslav et al., 1999). In order to minimize business risks, more often than not entrepreneurs start with neighboring countries which they are familiar with and similar in terms of culture, society and economy.

Notwithstanding of the importance of internationalization, research pertaining to the involvement of SME entrepreneurs in international trade is still limited, especially in Malaysia and South East Asia. As a result, not much literature pertaining to internationalization is available. A browse on the Google scholar using the keywords 'entrepreneurship across borders ASEAN' found only 12,000 results, on the contrary the same keywords for EU produced 38,700. At country level involving Malaysia produced 21,000 results and Thailand 23,000 results, the results were higher for England and Australia, with the results of 37,000 and 34,000 respectively.

This paper investigates the level of international business knowledge among entrepreneurs in Narathiwat province, Thailand. Researching international knowledge is important because it is a prerequisite for internationalization. By doing so, this research tries to fill the void of literature and at the same time contribute to internationalization theory in the context of developing countries in general and Thailand in particular.

\subsection{Background of Narathiwat, Thailand}

Narathiwat is one of the seventy-seven provinces in the southern provinces of Thailand. Other neighbouring provinces are Yala and Pattani and to the south, it borders the Malaysian state of Kelantan. Narathiwat is one of the nation's five provinces that include Yala, Pattani, Songkhla, and Satun, that borders Malaysia. The province features a range of cultures as well as natural resources, and is relatively fertile. Narathiwat is about 1,140 kilometres south of Bangkok and has an area of 4,475 square kilometres. Seventy-five per cent of the area is jungle and mountains, and experiences a tropical climate (https://en.wikipedia.org/wiki/narathiwat_province).

Historically, Narathiwat was part of the semi-independent Malay Sultanate of Pattani, paying tribute to the Thai kingdoms of Sukhothai and Siamese kingdom of Ayuthia. After Ayutthaya fell in 1767, the 
Sultanate of Pattani gained full independence, but not too long; under King Rama I it again came under Thai control for 18 years, later and in the early 1800s it was divided into 7 smaller kingdoms. In 1909, Narathiwat was fully integrated into Siam as part of the Anglo-Siamese Treaty negotiated with the British. Along with Yala, Narathiwat was then part of the Pattani County (Monthon) and is now one of the four Thai provinces which have a Muslim majority population $(82 \%)$ while the rest $(17.9 \%)$ are Buddhists. $80.4 \%$ of the Narathiwat Malays, who are largely farmers and fishermen, speak the Melayu dialect as their first language and are very similar in ethnicity and culture to the Malays of Kelantan, Malaysia (https://en.wikipedia.org/wiki/narathiwat_province).

Since the 7th of September 2001, the Thai federal government introduced a local policy to support the One Tambon One Product (OTOP) project. The project aims to support locally made and marketed products of each Thai Tambon (sub-district). Drawing its inspiration from Japan's successful One Village One Product (OVOP) program, the OTOP program encourages village communities to improve the local products' quality and marketing strategy, selecting one outstanding product from each Tambon to receive formal branding as its "starred OTOP product". OTOP is a local entrepreneurship stimulus program initiated by Thailand's former H.E. Prime Minister Thaksin Shinawatra during his tenure from 2001 to 2006 that provides both local and national platforms to promote local products. OTOP products include a large array of local products, including traditional handicrafts, cotton and silk garments, pottery, fashion accessories, household items and food. The philosophy of OTOP is to help communities prosper and raise the standard of living by turning available local resources into quality products. Featuring their own cultural uniqueness as a marketing tool, both domestically and overseas, these products abide by the following three basic principles: local yet global, self-reliance creativity, and human resource development. The product does not stand alone, but includes a process of thought that include services, natural resources and environmental protection. In addition, these products are imbued with Thai wisdom in art, culture and tradition while conserving local knowledge in order to become the hallmark of Thai identity and excellence. This has become the selling point of Thai products and is known across the country and around the world. The implementation of the OTOP project has the following objectives: creating job opportunities and generating income for the community; enabling the community to think and work by themselves; promoting local wisdom; promoting human resource development; promoting initiative on the part of the community to develop products in accordance with their environment and local cultures (Natsuda et al.2012).

After a military junta overthrew Thaksin's government in 2006 following an invalid election results due to alleged irregularities, the OTOP program was stopped. However, it was soon revived and rebranded. Thailand had about 2.8 million SMEs in 2008, more than triple the number accounted for in 1997-98. This increase is partly attributed to better measuring and monitoring of SMEs, and to the natural growth of the SMEs. They have the highest levels of early stage entrepreneurship in the world (Virasa et. al, 2007) as measured by the Global Entrepreneurship Monitor (GEM) and Total

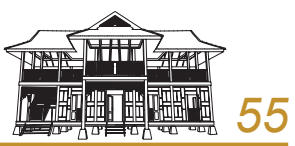


Entrepreneurial Activity (TEA) indicator, which measures the proportion of adults engaged in starting up a business in the previous 42 months; Thailand had an average TEA of $20.5 \%$ for the period 2002-07. Thailand had a relatively high level of female participation in early stage and established business entrepreneurship. About 30\% of entrepreneurs in Thailand are "necessity" entrepreneurs, that is, they start a business because they do not really have an alternative way of attempting to generate an income. The other $70 \%$ of entrepreneurs are pursuing a business opportunity (Virasa et. al, 2007, 2006, 2005).

The Narathiwat and Thai federal governments allocate their budget towards entrepreneurs to promote and develop the quality and standard of their products, and to participate in knowledge sharing, marketing management, packaging, business matching and networking especially with the bordering state of Kelantan Malaysia. This promotion also includes the inclusion of culture and tradition to bring lasting peace and happiness for the people, not only for trading, but also to build relationships. The government is ever willing to facilitate entrepreneurs in Narathiwat and give overwhelming support and help them to develop management skills. Entrepreneurs are assisted in areas such as production, packaging, advertisement, market system, including laws and protocols of both countries, especially on Halal, Food and Drug licenses, customs and border crossing procedures. They are also involved in business matchings and networking between entrepreneurs and distributors to enhance their trade, international business and relations.

When ASEAN Community 2015 was implemented, the most important things entrepreneurs need to develop for international business knowledge are in the following areas: (1) The nine International Business Regulations: Custom protocol, Immigration protocol, Quarantine protocol, Product kind import and export regulation, Product volume import and export regulation, Product certification import and export regulation, Mode of payment, Tax \& Tariff, and International business law. (2) International Networking: Business networking, Business matching, International market. (3) International Financial Management: International accounting, Foreign Direct Investment (FDI), Capital procurement, and financial management. (4) Logistics and Distributive Trade: Material procurement, Material management, Inventory management, Equipment maintenance, and Transporting or Logistics system. (5) Enterprise Image: Advertisement, Ethics, Professionalism, and Social Responsibility. (6) Public Policy and Business Opportunity: Public policy of international business, Opportunity on political security, and Opportunity on socio-culture. (7) AEC: ASEAN Community beyond 2015, APSC: ASEAN Political-Security Community, AEC: ASEAN Economic Community, ASCC: ASEAN Socio-Cultural Community, and IMT-GT: Indonesia, Malaysia, and Thailand Growth Triangle (www. adb.org). 


\subsection{Research objectives}

1. To study the level of knowledge on international business among Narathiwat entrepreneurs.

2. To provide preliminary information to the local Narathiwat authority and Thai federal government in order to formulate a public policy to support the dissemination of new knowledge on international business to Narathiwat entrepreneurs beyond AEC.

\subsection{Research Methodology}

Thirty entrepreneurs were randomly selected in April 2014 to gauge their knowledge on international business which include: (1) International Business Regulations (2) International Networking (3) International Financial Management (4) Logistics and Distributive Trade (5) Enterprise Image: Advertisement, Ethics, Professionalism, and Social Responsibility (6) Public Policy and Business Opportunity and (7) AEC .

\subsection{Research Findings}

\subsection{Demography}

In this research most of the respondents are female, 70 per cent and 30 per cent are male. Majority of respondents' ages ranged from 51-60 years old (39.3\%). Most respondents earn an income of 10,000 Baht or lower per month (68\%). In terms of education, majority of respondents, close to 37 per cent studied up until secondary school, only 23.4 per cent pursued their studies at tertiary level. Almost 80 per cent of the respondents are married. Respondents' social positions were quite diverse, such as sub-district Exco, lecturers and teachers. Majority of them are civil servants. In terms of language, majority of them use the Thai language (60 per cent), less than 40 per cent are capable of using both Thai and Malay languages. Only a small percentage can communicate in English. 
Table 1: Demography of respondents

\begin{tabular}{|c|c|c|}
\hline Demography & Frequency & Percentage \\
\hline \multicolumn{3}{|l|}{ Gender } \\
\hline Male & 9 & 30.0 \\
\hline Female & 21 & 70.0 \\
\hline Total & 30 & 100.0 \\
\hline \multicolumn{3}{|l|}{ Age (years) } \\
\hline $21-30$ & 1 & 3.6 \\
\hline $31-40$ & 4 & 14.3 \\
\hline $41-50$ & 8 & 28.6 \\
\hline $51-60$ & 11 & 39.3 \\
\hline 61 or upper & 4 & 14.3 \\
\hline Total & 28 & 100.0 \\
\hline \multicolumn{3}{|l|}{ Income } \\
\hline 10,000 Baht or lower & 17 & 68.0 \\
\hline $10,001-20,000$ Baht & 8 & 32.0 \\
\hline Total & 25 & 100.00 \\
\hline \multicolumn{3}{|l|}{ Educational level } \\
\hline No schooling completed & 2 & 6.7 \\
\hline Primary school & 6 & 20.0 \\
\hline Lower secondary school & 2 & 6.7 \\
\hline Upper secondary school & 9 & 30.0 \\
\hline Lower vocational college & 1 & 3.3 \\
\hline Upper vocational college & 2 & 6.7 \\
\hline Diploma & 2 & 6.7 \\
\hline Bachelor's degree & 5 & 16.7 \\
\hline Master's degree & 1 & 3.3 \\
\hline Total & 30 & 100.0 \\
\hline \multicolumn{3}{|l|}{ Marital status } \\
\hline Single & 3 & 11.1 \\
\hline Married & 21 & 77.8 \\
\hline Divorced & 1 & 3.7 \\
\hline Widowed & 2 & 7.4 \\
\hline Total & 27 & 100.0 \\
\hline
\end{tabular}


Table 1: (Continued)

\begin{tabular}{|l|c|c|}
\hline \multicolumn{1}{|c|}{ Demography } & Frequency & Percentage \\
\hline Village header & 1 & 3.3 \\
\hline Village committee & 2 & 6.7 \\
\hline Sub district Exco & 6 & 20.0 \\
\hline Local officer & 4 & 13.3 \\
\hline Teacher or Lecturer & 4 & 13.3 \\
\hline Volunteer & 2 & 6.7 \\
\hline Other social group member & 5 & 16.7 \\
\hline Other & 6 & 20.0 \\
\hline Total & 30 & 100.0 \\
\hline Languages used & & 60.0 \\
\hline Thai & 18 & 36.7 \\
\hline Thai and Malay & 11 & 3.3 \\
\hline Thai and English & 1 & 100.0 \\
\hline Total & 30 & \\
\hline
\end{tabular}

\subsection{Respondents' International business knowledge}

Respondents' level of knowledge on international business is shown in Table 2. As far as international business regulation is concerned, the results show 16 respondents $(53.3 \%)$ have no knowledge about international business regulation, other 10 respondents $(33.3 \%)$ have slight knowledge and 4 respondents (13.3\%) have average knowledge. None of them claimed to have high or very high knowledge on the matter. As for next item 19 respondents $(63.3 \%)$ have no knowledge about international networking, other 4 respondents $(13.3 \%)$ have slight knowledge and 7 respondents $(23.3 \%$ ) have average knowledge. In terms of international financial management, 19 respondents $(63.3 \%)$ have no knowledge, only 8 respondents $(26.7 \%)$ have slight knowledge, followed by 2 respondents $(6.7 \%)$ who have average knowledge and 1 respondent $(3.3 \%)$ with high knowledge. As for logistics and distributive trade, 18 respondents $(60.0 \%)$ have no knowledge and 12 respondents $(40.0 \%)$ have slight knowledge. 16 respondents (53.3\%) have no knowledge about enterprise image, other 12 respondents $(40.0 \%)$ have slight knowledge and 2 respondents $(6.7 \%)$ have average knowledge. As for the public policy and business opportunity, 16 respondents $(53.3 \%)$ have no knowledge about public policy and business opportunity, other 11 respondents (36.7\%) have slight knowledge, followed by 2 respondents $(6.7 \%)$ with average knowledge and 1 respondent $(3.3 \%)$ with high knowledge. As for the last item, ASEAN Economic Community (AEC) 11 respondents (36.7\%) have no knowledge about $A E C$, other 11 respondents (36.7\%) have slight knowledge, 7 respondents

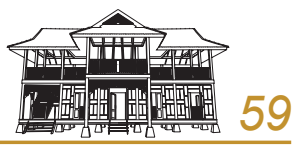


(23.3\%) have average knowledge, and 1 respondent (3.3\%) with high knowledge.

Table 2: Respondents International Knowledge

\begin{tabular}{|c|c|c|c|c|c|}
\hline & $\begin{array}{l}\text { Not at all } \\
\text { knew }\end{array}$ & $\begin{array}{c}\text { Slightly } \\
\text { knew }\end{array}$ & Knew & Very knew & $\begin{array}{c}\text { Extremely } \\
\text { knew }\end{array}$ \\
\hline $\begin{array}{l}\text { 1. International Business } \\
\text { Regulation }\end{array}$ & $16(53.3 \%)$ & $10(33.3 \%)$ & $4(13.3 \%)$ & - & - \\
\hline 2. International Networking & $19(63.3 \%)$ & $4(13.3 \%)$ & $7(23.3 \%)$ & - & - \\
\hline $\begin{array}{l}\text { 3. International Financial } \\
\text { Management }\end{array}$ & $19(63.3 \%)$ & $8(26.7 \%)$ & $2(6.7 \%)$ & $1(3.3 \%)$ & - \\
\hline 4. Logistics and Distributive Trade & $18(60.0 \%)$ & $12(40.0 \%)$ & - & - & - \\
\hline 5. Enterprise Image & $16(53.3 \%)$ & $12(40.0 \%)$ & $2(6.7 \%)$ & - & - \\
\hline $\begin{array}{l}\text { 6. Public Policy and Business } \\
\text { Opportunity }\end{array}$ & $16(53.3 \%)$ & $11(36.7 \%)$ & $2(6.7 \%)$ & $1(3.3 \%)$ & - \\
\hline 7. AEC & $11(36.7 \%)$ & $11(36.7 \%)$ & $7(23.3 \%)$ & $1(3.3 \%)$ & - \\
\hline
\end{tabular}

Judging from respondents' answers of all 7 items of international business knowledge, except for AEC, the study clearly shows that respondents had rather no or little knowledge about international business. Majority of respondents chose not at all knew about these 6 items. As for AEC, sizeable respondents claimed they slightly knew and knew about it. Comparing all the items, the researchers found respondents had some knowledge about AEC.

\subsection{Discussion}

By and large, the results of this study show respondents in general had no or little knowledge about international business. This result came as a no surprise as majority of SMEs entrepreneurs in Narathiwat involved in this survey consisted of those who only run their business in home country and interested to expand their businesses overseas but yet to do so. They involved in various business activities to cater local market. Although many Thais products such as clothes, fruits as well as foods widely available in the bordering towns in Kelantan like Rantau Panjang and Pengkalan Kubur and to the capital Kota Bharu the findings of this research did not show entrepreneurs in Narathiwat had some knowledge about internationalization. Hence, the findings of early investigation of internalization actually provide more questions than the answers. Firstly, who actually dominated businesses between borders? Secondly, if Thai's products flooded the Malaysian-Thai borders why SMEs did not know about ways of doing international business? Thirdly, is mobility of goods to Malaysian's border occurred illegally? What capability of SMEs to embark in internalization? Lastly, did the Ministry, in regards to internalization, fail to encourage entrepreneurs to be involved in international business?

TENIAE 
Despite general low level of knowledge of respondents in Narathiwat in internalization, respondents' scores on AEC showed they knew about it. This was due the efforts of Thai government that provided information about $A E C$ in various programs and courses to encourage local entrepreneurs to embark on internalization. AEC will be launched at the end of 2015 and with the implementation of AEC it is expected of freer mobility of goods amongst ASEAN countries. Accordingly, Narathiwat and Thai federal government should realize to make a bold decision and formulate the public policy to support and foster new knowledge about international business among entrepreneurs who will involve internationally. This include those who in pre-nascent and nascent entrepreneurial stage and all of entrepreneurs in Narathiwat beyond AEC 2015. By so doing they could be incremental internationalization of their SMEs and the owner-managers' experience effects on internationalization performance. Strong international experience of entrepreneurs can be seen as an antecedent of an international new venture.

\subsection{Conclusion}

In conclusion, it was found that almost all entrepreneurs had little knowledge about international business knowledge. This includes low knowledge in international business regulation international financial management, public policy and business Opportunity, except in AEC it is known more in enterprise image. International networking is very known, however in logistics and distributive trades are nearly unknown. Therefore, Narathiwat and Thai federal government should realize and take this into consideration to make decision and formulate the public policy to support and foster new knowledge about international business for all entrepreneurs in Narathiwat until they could have some knowledge in international business. Narathiwat and Thai federal government should take an effort to increase entrepreneurs' international knowledge. An international orientation, training, and exposure with various international transaction activities can be done incrementally. 


\section{Rujukan}

Asian Development Bank. Retrieved 20 Jun 2014. www.adb.org/features/asean-economic-community-12 things-know.

Carlos, W. M, William J.P, Leslie E. P, and Justin G. L.(2010) Managing Small Business, $15^{\text {th }}$ edition. South-Western Cangage Learning. China Translation \& Printing Services Limited. 2010.

Jeanne, H. (2007). Principles of Entrepreneurship. Bureau of International Information Programs, U.S. Department of State.

John, D. , Lee H. R., and Daniel P.S. (2012). International Business: Environments and Operations, 14th edition. Pearson Education Limited.

Miroslav, G., Robert D. H., Ales. V and Bostjan. A. (1999), The Internationalization of SMEs in Transition Economies: evidence from Slovenia.

Narathiwat Province. Retrieved 19 Jun 2014, from https://en.wikipedia.org/wiki/narathiwat_province.

Natsuda, K.,Igusa, K., Wiboonpongse, A., \& Thoburn, J. (2012). One Village one Product - Rural Development Strategy in Asia: The Case of OTOP in Thailand. Canadian Journal of Development Studies, 33(3), 369-385.

Robert, G. and Jack N. B..(1992). Theory in international business. Transnational Corporations, 1(1), 93126.

Virasa, T., B. H, R. Shannon and Zhi M.(2005), “GEM Thailand Report 2005”, Global Entrepreneurship Monitor, Bangkok.

Virasa, T. and Hunt, B. (2007), "GEM Thailand 2007 Report”, Global Entrepreneurship Monitor, Bangkok.

Virasa, T., B. H., . Shannon, R and Zhi, T. M (2006), “Thailand GEM 2006 National Team Report”, Global Entrepreneurship Monitor, Bangkok. 